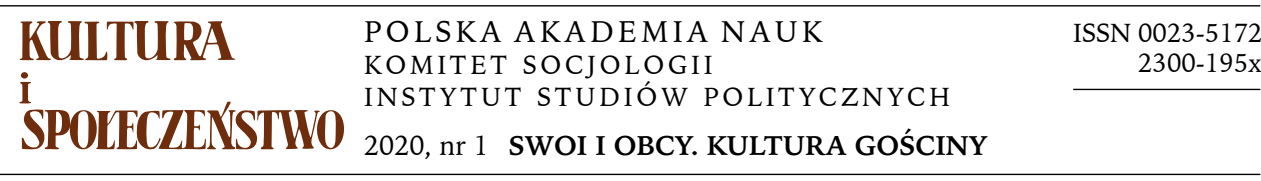
$\begin{array}{lllllllll}A & R & T & Y & K & U & £ & Y\end{array}$
I
$\begin{array}{llllllll}\mathrm{R} & \mathrm{O} & \mathrm{Z} & \mathrm{P} & \mathrm{R} & \mathrm{A} & \mathrm{W} & \mathrm{Y}\end{array}$

KRZYSZTOF BIERWIACZONEK, TOMASZ NAWROCKI Uniwersytet Ślaski

\title{
PRACA W PAMIĘCI ZBIOROWEJ MIESZKAŃCÓW GÓRNOŚLĄSKIEJ WSI NA TLE PROCESÓW PRZEMIAN OBSZARÓW WIEJSKICH
}

Tematem tej analizy jest pamięć zbiorowa mieszkańców górnośląskiej wsi Bojszowy dotycząca sfery pracy. Wybór takiej tematyki ma trzy uzasadnienia. Po pierwsze, dla badanej społeczności (Bojszowy nie są tu wyjątkiem) praca stanowi istotną wartość kształtującą jej tożsamość. Również pamięć zbiorowa jest elementem tożsamości społecznej (Assmann 1995, s. 130; Nowak 2011, s. 10, 12, 53-55; Eyerman, Madigan, Ring 2017). Interesujące jest zatem pokazanie, w jakim stopniu pamięć o pracy jest elementem ważnym dla mieszkańców Bojszów. Po drugie, sfera pracy, rozumiana jako realizacja różnego rodzaju obowiązków (zawodowych, gospodarskich) przynależnych do trybu konieczności (Martini 2017, s. 99), nie jest częstym tematem opracowań poświęconych pamięci zbiorowej. Po trzecie, pamięć o pracy i zmianach, jakie następowały w tej sferze w XX wieku, jest interesującym odzwierciedleniem przemian zachodzących na wsi, w tym przypadku na Górnym Śląsku, w ciągu kliku ostatnich dziesięcioleci.

Analiza dotycząca zasobów pamięci zbiorowej bojszowian w odniesieniu do sfery pracy została tu podzielona na dwie części, które dotyczą czasu przed drugą wojną światową i lat Polski Ludowej. Prezentację ustaleń em-

Adres do korespondencji: krzysztof.bierwiaczonek@us.edu.pl, ORCID: 0000-0002-8375-2800; tomasz.nawrocki@us.edu.pl, ORCID: 0000-0001-5988-8006 
pirycznych poprzedza refleksja teoretyczna na temat pamięci zbiorowej i zagadnień metodologicznych oraz krótki opis badanej miejscowości.

\section{PAMIĘĆ ZBIOROWA — KILKA UWAG TEORETYCZNYCH}

Przyjmuje się, że początkiem naukowych studiów nad pamięcią zbiorową były prace Maurice'a Halbwachsa i Aby Warburga (Saryusz-Wolska 2011, s. 56). W polskiej historii memory studies ważne są studia Stefana Czarnowskiego (a zwłaszcza jego analiza legendy o św. Patryku oraz refleksje o znaczeniu przeszłości w teraźniejszości), które zostały napisane w czasie podobnym co kanoniczne dla memory studies prace Halbwachsa i Warburga (zob. np. Kończal, Wawrzyniak 2018, s. 394). Koncepcję Halbwachsa uznaje się za początek studiów nad społeczną perspektywą badań pamięci, a Warburga nad perspektywą kulturową (Assmann 1995, s. 125; Saryusz-Wolska 2011, s. 56). Poniższe rozważania lokują się w Halbwachsowskiej perspektywie rozumienia pamięci zbiorowej, w której kluczowe jest sformułowanie: „człowiek w społeczeństwie nabywa wspomnienia, rozpoznaje je i lokalizuje" (Halbwachs 2008, s. 4). W takim ujęciu pamięci nie można analizować bez jej społecznego kontekstu. Zwracała na to uwagę Barbara Szacka (2006, s. 44), pisząc, że zbiorowa pamięć przeszłości to:

„[...] wyobrażenia o przeszłości własnej grupy, konstruowane przez jednostki z zapamiętanych przez nie [...] informacji pochodzących z różnych źródeł i docierających do nich rozmaitymi kanałami. Są one rozumiane, selekcjonowane i przekształcane zgodnie $z$ własnymi standardami kulturowymi i przekonaniami światopoglądowymi. Standardy te są wytwarzane społecznie, a zatem wspólne członkom danej zbiorowości, co prowadzi do ujednolicania wyobrażeń o przeszłości i tym samym pozwala mówić o pamięci zbiorowej dziejów własnej grupy".

W definicji tej uwaga zostaje zwrócona na różnorodne źródła, z których budowana jest pamięć. Znaczenie tego faktu podkreślają także Christopher J. Hewer i Ron Roberts (2012, s. 171-173), formułując model dynamiki pamięci zbiorowej doświadczanej przez jednostkę w określonej kulturze. Świadomość jednostki (subjective reality) w odniesieniu do przeszłości kształtują, według nich, indywidualne doświadczenia, pamięć zbiorowa funkcjonująca $w$ danej społeczności oraz historia (w znaczeniu opracowań o charakterze naukowym, akademickim). Te trzy sfery wpływają na siebie wzajemnie poprzez podzielaną społecznie znajomość publikacji historycznych, tekstów biograficznych, ale także poprzez procesy komunikacji i wymiany informacji pomiędzy jednostkami. Tym samym zasoby pamięci jednostkowej są efektem społecznej mediacji i wpływu zbiorowości, do 
której jednostki przynależą. Wpływ zbiorowości dokonuje się w procesie komunikacji z innymi (zob. Assmann 1995, s. 127), a - jak pokazują badania psychologów - „ludzie często rozmawiają z innymi członkami swojej społeczności o przeszłych wydarzeniach i ich konsekwencjach dla teraźniejszości" (Coman i in. 2009, s. 130). Nawet jeśli sformułowanie o częstych rozmowach o przeszłości jest nazbyt optymistyczne, to niewątpliwie mają one miejsce i wpływają na kształtowanie pamięci zbiorowej. Innymi słowy, pamięć jednostkowa składa się z przenikających się własnych i zapośredniczonych doświadczeń (zob. Giddens 2006, s. 314).

W procesie komunikacji między jednostkami, podczas dzielenia się własnymi wspomnieniami czy przeżyciami oraz w sytuacji konfrontowania ich $z$ akademicką wersją historii może dochodzić do uwspólniania wersji przeszłości i jej konstruowania. Taki proces nierzadko ma na celu ustalenie wspólnotowej wersji przeszłości, często istotnej ze względu na teraźniejszość danej społeczności (Lowenthal 1991; Robotycki 1997). Wspólna wersja przeszłości jest ważna ze względu na tożsamość społeczną danej grupy. „Przeszłość staje się ważnym elementem tożsamości tych, którzy do tej przeszłości się przyznają" — zauważa Jacek Nowak (2011, s. 54). W ten sposób jednostki potwierdzają swoją przynależność do grupy, zwłaszcza jeśli wspomnienia odnoszą się do powszechnie podzielanej sfery kultury, na przykład pracy. Tym samym kreowana jest swoista wspólnota pamięci (Nijakowski 2008, s. 145).

Pisząc o znaczeniu komunikacji społecznej w procesie kreowania pamięci zbiorowej nie można zapominać o zaproponowanym przez Jana Assmanna podziale na pamięć komunikacyjną (komunikatywną) i pamięć kulturową. Pamięć komunikacyjna obejmuje wspomnienia dotyczące najbliższej przeszłości osiemdziesięciu-stu lat historii danej społeczności (Assmann 1995, s. 127; Rajewski 2013, s. 189), a jej nosicielami są niewyspecjalizowani świadkowie wspólnoty pamięci. Pamięć kulturowa zaś zorientowana jest na utrwalone punkty z przeszłości. Tu liczą się nie tyle fakty, ile historia zapamiętana i nośniki trwale zobiektywizowane (Assmann 2009, s. 82-88). Gdy odchodzi pokolenie będące strażnikiem pamięci swoich czasów, pojawia się dryfująca luka (floating gap) i społeczność przechodzi od pamięci komunikatywnej do pamięci kulturowej (Assmann 2009, s. 80-82; por. Kaźmierska 2012, s. 47).

W tej analizie koncentrujemy się na komunikacyjnej pamięci zbiorowej (zob. Welzer 2010). Tylko bowiem w procesie komunikacji jednostki ujawniają swoją pamięć o przeszłości. Bez ujawniania własnych wspomnień czy relacji z przeszłości pamięć ma wymiar indywidualny, intersubiektywnie niedostępny. 


\section{BOJSZOWY — KRÓTKA CHARAKTERYSTYKA BADANEJ MIEJSCOWOŚCI}

Gmina Bojszowy leży w powiecie bieruńsko-lędzińskim w województwie śląskim w bliskiej odległości od Tychów (około $11 \mathrm{~km}$ ), Pszczyny (około $14 \mathrm{~km}$ ), Katowic (około $30 \mathrm{~km}$ ) i położonego już w Małopolsce Oświęcimia (około $10 \mathrm{~km}$ ). W skład gminy wchodzi pięć wsi: Bojszowy, Jedlina, Bojszowy Nowe, Świerczyniec i Międzyrzecze. Od 2017 roku Bojszowy należą do Górnośląsko-Zagłębiowskiej Metropolii. Położenie na granicy Górnego Śląska i Małopolski oraz na skraju Górnośląskiego Okręgu Przemysłowego było istotne dla historii tej miejscowości i jej mieszkańców co najmniej z dwóch względów: gospodarczych i kulturowych, czyli (1) powiązań z procesem industrializacji zachodzącym na Górnym Śląsku i Zagłębiu od początku XIX wieku oraz (2) pograniczności Bojszów i możliwości częstszych kontaktów z bliskimi „obcymi” (np. na targach w Oświęcimiu). Ten drugi wątek nie będzie tu rozwijany.

Zanim Bojszowy zetknęły się z procesem industrializacji rozwój miejscowości przebiegał typowo. Pierwsza wzmianka datowana jest na rok 1368 (Lipok-Bierwiaczonek 2018, s. 7). Późniejsze informacje są bardzo skąpe. Wiadomo, że w 1577 roku powstał kościół parafialny (Kaczmarek 2018, s. 17-18). Dokładniejsze dane dotyczą poprzedniego stulecia. Na początku XX wieku, w 1904 roku, w Bojszowach było 125 domów, a w rok później spis wykazał, że w miejscowości mieszkało 1174 mieszkańców (razem z sąsiednią Jedliną często ujmowaną w statystykach łącznie z Bojszowami). W 1904 roku poświęcono także nowy, ceglany, neogotycki kościół parafialny (Lysko 2002, s. 13-14).

Dane $z$ lat trzydziestych XX wieku świadczą o dalszym rozwoju demograficznym miejscowości - w roku 1931 Bojszowy wraz z Jedliną liczyły 1811 mieszkańców (Lysko 2002, s. 46-47). Podczas drugiej wojny światowej zostały włączone w granice Rzeszy. Lata wojenne, poza zmianą władzy i represjami wobec tych, którzy nie chcieli się podporządkować nowym porządkom, były związane $\mathrm{w}$ Bojszowach $z$ trudnym sąsiedztwem obozu koncentracyjnego w Oświęcimiu, przymusowymi pracami, a przede wszystkim powołaniami do wojska. W czasie drugiej wojny światowej do Wehrmachtu wcielono łącznie 400 mieszkańców gminy Bojszowy, 49 z nich zginęło (Lysko 2002, s. 69).

Po drugiej wojnie światowej miejscowość zachowała dotychczasowy charakter. Z perspektywy mieszkańców większą zmianą było ulokowanie, w pobliżu Bojszów kopalni i innych zakładów przemysłowych (między innymi kopalni Ziemowit w Lędzinach, kopalni Czeczott w Woli, Fabryki Samochodów Małolitrażowych w Tychach). W 1976 roku liczba mieszkań- 
ców Bojszów wynosiła 2480 osób (całej gminy 5607 osób) (Lysko 2002, s. 133-134).

Współcześnie Bojszowy zyskują nowych mieszkańców. W latach 1999_ -2014 dynamika wzrostu liczby mieszkańców plasowała je na drugim miejscu wśród gmin województwa śląskiego (po Wyrach) (Runge 2017, s. 47). Bojszowy można traktować jako miejscowość rezydencjalną na skraju Górnośląsko-Zagłębiowskiej Metropolii.

Tabela 1

Liczba ludności w gminie Bojszowy i miejscowościach wchodzących w jej skład (lata 1991 i 2015)

\begin{tabular}{|l|c|c|c|c|c|c|}
\hline $\begin{array}{c}\text { Liczba } \\
\text { ludności }\end{array}$ & Bojszowy & $\begin{array}{c}\text { Bojszowy } \\
\text { Nowe }\end{array}$ & Jedlina & $\begin{array}{c}\text { Międzyrze- } \\
\text { cze }\end{array}$ & $\begin{array}{c}\text { Świerczy- } \\
\text { niec }\end{array}$ & $\begin{array}{c}\text { Gmina } \\
\text { Bojszowy }\end{array}$ \\
\hline w 1991 r. & 2792 & 1012 & 362 & 677 & 728 & 5571 \\
w 2015 r. & 3593 & 1302 & 476 & 853 & 1310 & 7534 \\
Wzrost (w \%) & 28,69 & 28,66 & 31,49 & 26,00 & 79,95 & 35,23 \\
\hline
\end{tabular}

Źródło: Strategia Rozwoju Gminy Bojszowy na lata 2016-2026, Bojszowy 2016.

\section{METODOLOGIA BADAŃ NAD BOJSZOWSKĄ PAMIĘCIĄ ZBIOROWĄ}

Bojszowy zostały wybrane jako miejsce badań nad pamięcią zbiorową $z$ dwóch przyczyn. Po pierwsze, miejscowość ta występowała jako odniesienie we wcześniejszych badaniach prowadzonych w gminach Górnego Śląska (zob. Bierwiaczonek, Nawrocki, Tyrybon 2001; Nawrocki 2006). Jawiła się jako ważna dla śląskiej kultury i tożsamości, co sprzyjało zainteresowaniu badawczemu. Drugą, bezpośrednią przyczyną były zorganizowane przez gminę w 2018 obchody 650 rocznicy pierwszej udokumentowanej pisemnej informacji o Bojszowach. Była to okazja do świętowania, a także pretekst do refleksji na temat przeszłości miejscowości. Zostaliśmy zaproszeni do przeprowadzenia badań nad pamięcią zbiorową bojszowian, co umożliwiło nam realizację odkładanego przez lata projektu badań socjologicznych w Bojszowach. Badania bojszowskie, choć osadzone lokalnie, wpisują się tw formułowany współcześnie postulat intensyfikacji zainteresowania pamięcią zbiorową Górnoślązaków (Szmeja 2017, s. 266; Gerlich 2016).

W bojszowskim projekcie badawczym uwaga została skoncentrowana na komunikacyjnym aspekcie pamięci zbiorowej, co pociągnęło za sobą wybór określonych technik badawczych. Wykorzystano klasyczną socjo- 
logiczna technikę wywiadu pogłębionego, który był przeprowadany na podstawie wcześniej przygotowanych dyspozycji (Mayntz, Holm, Hübner 1985, s. 132-133; Babbie 2003, s. 327-330). Uzyskane w ten sposób wypowiedzi badanych potraktowno jako swoiste konstrukty, w których badani świadomie lub nieświadomie sprawują kontrolę nad opowiadaną historią (zob. Halamska 2018, s. 50).

Wybór jakościowej metody badawczej wynikał w największym stopniu $z$ celu samych badań, którym było zdobycie szerokiej i pogłębionej wiedzy na temat przeszłości Bojszów i ich społeczności. Pytania badawcze odnosiły się do miejsca, jakie w pamięci zbiorowej zajmują kluczowe zjawiska związane z przeszłym funkcjonowaniem bojszowskiej społeczności: życie rodzinne, relacje sąsiedzkie, praca, religia, wspomnienia związane $z$ wojną, przyroda, sfera aksjonormatywna, relacje z mieszkańcami sąsiednich miejscowości. Wywiady były nagrywane, a następnie transkrybowane. Tak przygotowany materiał badawczy został poddany analizie polegającej na kategoryzacji i typologizacji poszczególnych problemów badawczych. $\mathrm{W}$ tej analizie uwaga została skoncentrowana jedynie na pracy i jej znaczeniu jako elementu pamięci zbiorowej bojszowian. Ponadto wątek pracy stanowi interesującą ilustrację zmian społecznych i gospodarczych zachodzących w Bojszowach. Tym samym koncentrujemy się tu tylko na jednym $z$ pytań badawczych stawianych $w$ projekcie ${ }^{1}$.

W badaniach zastosowano celowy dobór respondentów. We współpracy z Urzędem Gminy w Bojszowach — zleceniodawcą badań ${ }^{2}$ - ustalono jakimi kryteriami powinni kierować się badacze. Najważniejsze to: długoletnie (przynajmniej dwudziestoletnie) zamieszkiwanie w Bojszowach, ciekawa (przynajmniej potencjalnie) biografia rodzinna lub zaangażowanie $\mathrm{w}$ prace organizacji działających na terenie Bojszów. Ponadto wśród respondentów miały znaleźć się osoby należące do różnych kategorii wiekowych - arbitralnie założono, że osoby powyżej 60 roku życia miały stanowić połowę próby badawczej. Jednym $z$ celów stawianych $\mathrm{w}$ badaniach było bowiem stwierdzenie, w jakim stopniu pamięć o przeszłości Bojszów różni się w zależności od przynależności pokoleniowej. W sumie podczas realizacji projektu od stycznia do kwietnia 2018 roku przeprowa-

${ }^{1}$ Całościowa analiza zebranego materiału badawczego została zaprezentowana w raporcie przekazanym Gminie Bojszowy. W zapowiedziach wydawniczych znajduje się też książka dotycząca bojszowskiej pamięci zbiorowej (Bierwiaczonek, Nawrocki 2020).

2 Realizacja badań była finansowana jako działanie w projekcie „Bojszowy - 650 lat wspólnoty nad brzegami Wisły — Gostyni — Pszczynki i Korzyńca (1368-2018)” ze środków Europejskiego Funduszu Rolnego na rzecz Rozwoju Obszarów Wiejskich: Europa inwestująca w obszary wiejskie. Projekt realizował Urząd Gminy w Bojszowach. 
Badani — płeć i wiek

\begin{tabular}{|l|c|c|c|}
\hline \multicolumn{1}{|c|}{ Badani } & Kobiety & Mężczyźni & Razem \\
\hline do 40 lat & 1 & 3 & 4 \\
41-60 lat & 3 & 8 & 11 \\
61-80 lat & 4 & 6 & 10 \\
powyżej 80 lat & 3 & 2 & 5 \\
\hline Razem & 11 & 19 & 30 \\
\hline
\end{tabular}

Źródło: badania własne.

dziliśmy osobiście 30 wywiadów: z 11 kobietami i 19 mężczyznami (zob. tabela 2).

Wśród badanych znalazło się 6 osób $z$ wykształceniem podstawowym, 2 z zawodowym, 12 ze średnim (technicznym lub ogólnym) oraz 10 z wyższym (co najmniej licencjackim). Poziom wykształcenia rozmówców był znacząco wyższy niż wskazywałaby ogólna struktura wykształcenia mieszkańców gminy (Zagała 2006, s. 34). Wśród 30 badanych 23 to urodzeni w Bojszowach, najczęściej pochodzący $z$ rodzin zakorzenionych we wsi lub takich w których przynajmniej jedno z rodziców pochodzi z Bojszów; 5 osób to mieszkańcy Bojszów, ale pochodzący z innych miejscowości, także tych, które znajdują się w granicach gminy, a dwójka badanych to rodowici mieszkańcy Jedliny (miejscowości wchodzącej w obręb gminy Bojszowy, historycznie ściśle związanej z Bojszowami).

W prezentacji materiału empirycznego będą przywoływane wypowiedzi badanych, niektóre dosyć szeroko. Wynika to między innymi z akceptacji postulatu Izabeli Bukraby-Rylskiej (2013, s. 530-531), która zwraca uwagę na znaczenie oddania głosu podmiotom badań socjologicznych.

\section{PRACA W PAMIĘCI ZBIOROWEJ — LATA MIĘDZYWOJENNE}

Lata międzywojenne, a zwłaszcza od lat trzydziestych XX wieku, to najdalszy okres pozostający w pamięci zbiorowej bojszowian. Relacje dotyczące tego okresu można określić jako okruchy pamięci. Wówczas Bojszowy były wsią rolniczą, choć pewna liczba mieszkańców pracowała $\mathrm{w}$ okolicznych zakładach przemysłowych. W pobliskich bieruńskich zakładach Lignoza, produkujących materiały wybuchowe, w 1934 roku zatrudniano 440 osób, około połowy $z$ nich stanowili bojszowianie, w tym kobiety. Jednocześnie nie rezygnowano $\mathrm{z}$ rolnictwa - w Bojszowach $\mathrm{w}$ tym czasie 
„pod pługiem” było 718 ha, a areał łąk i pastwisk wynosił 325 ha (Lysko 2002, s. 46-47, 51). Jednak w pamięci zbiorowej o pracy w latach międzywojennych dominuje wątek zatrudnienia w przemyśle i wychodzenia lub wyjeżdżania ku hutom (jak mówiono o pracy w górnośląskich zakładach przemysłowych).

Jak mój dziadek jeszcze byt to ku hutom godali. Na kopalni robili, ale nie tu, bo tu jeszcze nie byto wtedy ani "Ziemowitu” ani tego „Piastu” no to tam gdzieś ku hutom godali. A jak pojechali to na caty tydzień. Szli do pociagu na Nowy Bierun i z Nowego Bierunia tam jechali kaś ku Katowicom. [K_P1] ${ }^{3}$

Najczęstszym motywem wspomnień są właśnie opisy podróży ojców, dziadków, pradziadków (także najmłodsi badani dysponują takimi informacjami) do pracy ku hutom. Co ciekawe, częściej mówiono o docieraniu na miejsce pracy niż o samej pracy. Wydaje się, że może to wynikać $z$ faktu, że dla ówczesnych bojszowskich rodzin przyjazd po tygodniu pracy do domu i ponowny wyjazd były emocjonalnie ważne. Stąd też dosyć dokładne wypowiedzi o docieraniu do zakładu pracy pieszo, rowerem, a także pociągiem:

[...] bo dziadek w tym czasie pracowat na Gische, czyli na Giszowcu. Tam pracowat w kopalni. Jego tu nie byto praktycznie na miejscu. On przyjeżdżat na niedzielę i to nie na każda niedziele, no bo on musiat $z$ Nowego Bierunia piechota dojść, a z powrotem to już go furmanka zawieźli na pociag, żeby mógł do Katowic zajechać, ale normalnie jak przyjechał to nie wiedzieli, że przyjedzie, bo nie byto telefonów, tylko musiał $z$ tego Nowego Bierunia piechota isś przez Kopań, bo to jeszcze stare drogi byty. [...] Jak wrócit $w$ sobotę $w$ nocy może to $w$ niedziele posiedziat $i w$ niedziele wieczorem go musieli zawieźć na ten pociag, żeby on na rano mógł do pracy issć. [M_P2]

W tygodniu robotnicy górnośląskich fabryk i kopalni nocowali w szlaufhausach (domach noclegowych), gdzie warunki życia były bardzo skromne, a żywność często zabierano ze sobą z bojszowskiego domu.

I caty tydzień tam byli. Jak $w$ sobota przyjechali to chleba nabrali. Babka napiekta chleba, masta narobita no $i$ to oni se wzieli ten chleb tego masła, smalcu $i$ jeszcze tam

${ }^{3} \mathrm{~W}$ oznaczeniu wypowiedzi przywoływanych w tekście stosowane są skróty oznaczające płeć badanego (K i M) oraz jego przynależność pokoleniową: P1 — osoby powyżej 80 lat, P2 - osoby między 61-80 lat, P3 - osoby między 41 a 60 lat oraz P4 - osoby poniżej 40 roku życia. Zapis ograniczający liczbę informacji o respondencie wynika z konieczności zachowania anonimowości badanych. $\mathrm{Z}$ tego samego powodu w cytowanych wypowiedziach usunięto fragmenty, które mogłyby ujawnić rozmówców lub osoby, które były przez nich wspominane, zwłaszcza jeśli dotyczyło to wydarzeń lub informacji o drażliwym charakterze. Wypowiedzi zostały zachowane $\mathrm{w}$ dosłownym brzmieniu, $\mathrm{z}$ uwzględnieniem sformułowań gwarowych. W celu zrozumienia kontekstu wypowiedzi przytaczane jest pytanie zadawane przez badacza (stosowane są wówczas skróty: B (badacz) i R (rozmówca /informator). 
co mieli. Jak zabili co to mięsa $i$ tam se gotowali sami. Gadali w szlafhausie. Ugotowali i pojedli i za tydzień zaś przyjechali. Pieniądze przywieźli, reszta towaru nabrali i pojechali. [K_P1]

Ta ciężka praca i podróżowanie pomiędzy kopalnią lub fabryką a domem pozwalały bojszowianom zarobić pieniądze, które można było potem zainwestować w budowę domu lub w dokupienie pola.

Tata pracował na kopalni, na Wieczorku 4 [...] Mój tata miat pieniądze potem, kupit pole, 2,5 hektara. [K_P1]

Wtedy bardzo mało ludzi pracowało $w$ przemyśle. Tak jak dziadek pracowat w przemyśle to... Oni mieli pieniądz. [M_P2]

Wypowiedzi badanych wyraźnie wskazują, że w pamięci zbiorowej zachował się obraz różnic statusowych, które wynikały z tego, czy w danej rodzinie pracowano w okolicznych zakładach pracy, czy tylko zajmowano się rolnictwem. W społeczności bojszowskiej praca w przemyśle niewątpliwie była poważana, a bliskość rozwijającego się górnośląskiego przemysłu dawała szansę zarobkowania poza rolnictwem, a tym samym umożliwiała rozwój innych niż rolnicze kompetencji. We wsiach zlokalizowanych w pobliżu Górnośląskiego Okręgu Przemysłowego, stosunkowo szybko pojawiła się zatem dwuzawodowość rozumiana jako „łączenie pracy w rolnictwie i w innym sektorze, pracy związanej z regularnym, cyklicznym przemieszczaniem się ze wsi do miasta" (Bukraba-Rylska 2013, s. 258). W przypadku bojszowian w okresie międzywojennym często był to opisywany przez badanych rytm tygodniowy (zob. też Nawrocki 2006, s. 75-76). Warto przypomnieć, że na przełomie XIX i XX wieku $75 \%$ śląskiej klasy robotniczej nadal mieszkało na wsi i prowadziło gospodarstwa małorolne (Bukraba-Rylska 2013, s. 261). Wśród nich byli też bojszowianie.

Duże znaczenie przypisywane pracy w przemyśle może stanowić jeden $z$ powodów, dla których wspomnienia związane z pracą rolniczą były dużo rzadsze i miały lakoniczny charakter.

I kto miat gospodarstwo to robili na gospodarstwie $w$ domu. Konie mieli i robili a reszta to jeździli [ku hutom — przyp. aut.]. [K_P1]

Starsi badani czasem wspominali swoje dziecięce obowiązki w pracach polowych.

Rodzice mieli 5 hektarów i jeszcze kawałek wynajęty od księcia pszczyńskiego. Mieli krowa i jeszcze cielaki. I jeszcze koza. I ja to pieroństwo musiot paść. Ale nie szło -

\footnotetext{
${ }^{4}$ Rozmówczyni użyła współczesnej nazwy kopalni, która przed wojną nazywała się Giesche.
} 
matka kazała, to trzeba było. Koledzy szli latać, gonić się, a ja z moimi koleżankami na pole. [M_P1]

$Z$ relacji badanych bojszowian można wnioskować, że zestaw obowiązków dziecięcych $\mathrm{w}$ gospodarstwie w latach przedwojennych (a także powojennych) był podobny jak w innych wsiach Polski: „Zwykle już pięcioletnie dzieci przyuczane były do pierwszych lżejszych prac związanych $z$ pasaniem gęsi i innego ptactwa. Po nich przychodził czas na bydło oraz w zależności od płci dziecka stopniowo coraz bardziej skomplikowane prace męskie bądź kobiece" — zauważa Ewelina Szpak (2013, s. 134-135; por. Bukraba-Rylska 2013, s. 154-156; Szczepański 2003; Wesołowska 1991, s. 219).

Oprócz pracy w przemyśle i na gospodarstwach niektórzy bojszowianie opowiadali o innych sposobach zarobkowania. Jeden $z$ badanych wspominał terminowanie u rzemieślnika $\mathrm{w}$ sąsiednim niewielkim mieście.

Ojciec przed wojna pracowat dorywczo $w$ stolarni $u$ Kulasa $w$ Bieruniu, różne roboty dorywcze. To byty takie czasy, pierwsza wojna... Taki zastój to byt... Miat kolege Amerykanina [...], on byt lepiej sytuowany, to dalej się uczyt. A tam gdzie byty rodziny liczne, to nie byto tej edukacji. [M_P2]

Inny badany mówił o pracy w kuźni i konsekwencjach zdrowotnych z tym związanych:

Dziadek znowu J., który uczyt się kowalstwa w Mystowicach, bo to była rodzina kowali, on się ożenit z Z., moja babcia. Tu wybudowat kuźnię, której już nie ma, bo jest wyburzona. [...] Dziadek do końca byt kowalem, ale przedwcześnie zmart, bo kowale wtedy wdychali opary z tego... 80\% kowali umierało na astmę. I on też umart na astmę. [M_P3]

Ojciec kolejnego badanego pełnił funkcję miejscowego pisarza, który wydawał dokumenty urzędu stanu cywilnego. Były też rodziny tak biedne, że wynajmowały się do pracy u bogatych gospodarzy albo musiały posyłać na służbę dzieci:

Byli gospodarze, jak ktoś robi, to te dzieci od biedaków. [K_P1]

...bo za starej Polski brat już miał 17-18 lat, a ten szwagier byt starszy od niego $o$ dwa lata, a roboty nie byto to czasem ich brali ci gospodorze, co nie mieli $w$ domu takiej sity to brali tych kosiarzy co siekli. Jak byto lato to nawet o 4-5 [rano przyp. aut.] się szło siec, rosa byta fajna i zarobili chopcy coś. [M_P1]

Wspominano o osobach, które nie miały pracy. Zdarzało się, że utrzymywano się z kłusownictwa w okolicznych lasach.

Kłusowniki byty też. Jeden byt nagminny kłusownik. Nie mogli se z nim dać rady. Niejaki Jeszko. Nie żyje już, ale on tam strzelat co popadto, bo ludzie nie mieli pieniędzy. Zając albo sorna zabit i gotowali to i jedli. Bezrobocie byto bezwzględne. [M_P1] 
Mówiono też o pomocy udzielanej przez gminę bezrobotnym:

U sasiada była bieda, a u nas nie było biedy. Oni byli elwry i coś tam z gminy dostawali wsparcie.

B: Co to znaczy elwry?

R: Bezrobotny.

B: Nie chcieli pracować czy nie mogli?

R: Nie było roboty. To musiała gmina jakoś utrzymać. I to dostawali zapomogę: kawe, takie różne. To była taka profesjonalna kawa z cukrem, to byto takie dobre. To ja tej sasiadce tej stoniny ukrawałam, a ona mi tej kawy. To było dobre. [K_P1]

Praca zwykle była utożsamiana z pracą mężczyzn. Trzeba jednak zauważyć, że jeśli mężowie pracowali w zakładach przemysłowych w rytmie tygodniowym, to prowadzenie gospodarstwa spadało na ich żony wspierane przez dzieci i pozostających na wsi krewnych. Tym samym zmianie ulegał tradycyjny podział ról w rodzinie, według którego praca rolnicza jest domeną mężczyzn. Tradycyjny porządek rzeczy zaburzało też podejmowanie przez kobiety pracy w przemyśle. W przypadku Bojszów miejscem zatrudnienia najczęściej była Lignoza (powojenna nazwa ERG) - fabryka w sąsiednim mieście Bieruniu Starym. Jeden $z$ badanych zauważa, że miało to szczególne znaczenie w latach kryzysu:

R: No nie byto roboty formalnie. Pora tych kobietek co robiło $w$ tym zakładzie.

B: W Lignozie?

R: Tam było najwięcej zatrudnionych kobiet $w$ Lignozie. Przeważnie kobiety tam byty. Ino $w$ warsztatach co robili takie presy to tam było paru takich szpeców co robili $w$ tych mechanicznych warsztatach, a reszta na tych oddziałach produkcyjnych to kobiety wszystko. Nawet kobiety wybudowały se domy. A maż w doma siedziot. Dzieci pilnowat i obiady warzyt.

B: Takie byty przypadki? Tak odwrotnie...

R: Jo... Bo chopa tam nie potrzebowali. Bo potrzebowali fachowców, a jak nie miat zawodu albo szlifierza, albo tokarza albo ślusarza to go nie wzięli. A kobiety mieli do takich pospolitych robót. Różne tam byty roboty, ale tam pasowały kobiety najlepiej. [M_P1]

Praca $\mathrm{w}$ Lignozie nie zmieniała faktu, że zapewne w większości bojszowskich rodzin do kobiet należało prowadzenie domu, zajmowanie się dziećmi oraz tradycyjnie kobiece obowiązki w gospodarstwie (dojenie krów, pieczenie chleba) (zob. Bukraba-Rylska 2013, s. 153). Nie zaskakuje zatem, że rozmówcy na pytanie o pracę kobiet odpowiadali często tak jak jedna $z$ najstarszych badanych:

B: A mama co robita?

R: Mama zaś doma... nas byto siedmioro. [K_P1] 
W pamięci zbiorowej bojszowian o pracy w latach międzywojennych odzwierciedlenie znalazł wpływ procesu industrializacji na życie ich wiejskiej społeczności. Dotyczy to zarówno lokalnych przemian związanych ze sposobem produkcji rolnej i upowszechnieniem się kultury industrialnej (zob. Gorlach 2004, s. 70-73), jak i zmian zachodzących w bliskim sąsiedztwie, czyli uprzemysławiania Górnego Śląska. Można nawet przyjąć, że dzięki pracy sporej części mieszkańców w pobliskich zakładach przemysłowych w społeczności bojszowskiej następowało szczególne wzmocnienie kultury industrialnej i obustronna dyfuzja wzorów i norm kulturowych, związanych $z$ pracą $z$ jednej strony $w$ przemyśle, a $z$ drugiej $-w$ rolnictwie. Proces ten pogłębił się po drugiej wojnie światowej.

\section{PRACA W PAMIĘCI ZBIOROWEJ — LATA POLSKI LUDOWEJ}

Powojenny bojszowski świat pracy, zwłaszcza do lat siedemdziesiątych $\mathrm{XX}$ wieku, w zasadzie niewiele się różnił od przedwojennego. W tym czasie mówiąc o pracy bojszowianie nadal wspominali o łączeniu w rodzinach pracy na roli z zatrudnieniem w okolicznych zakładach przemysłowych.

[...] ale to pamiętam jak tata pracowot już tu, bo jako dziecko to już pamiętom i jak przyjeżdżat $z$ roboty to drap i na pole, drap i na pole. Pojeść szybko, bo już byto nastrojone, $i$ takie byto życie. $Z$ jednej roboty do drugiej. Mama nie pracowata, bo sie zajmowała domem i obejściem. [K_P2]

Jest to opis realizacji modelowego i typowego podziału ról związanych z obowiązkami zawodowymi i rodzinnymi (zob. np. Bukowska-Floreńska 2007, s. 127-136; Kijonka 2016, s. 131-132; Swadźba 2012, s. 41). Mężczyźni najczęściej pracowali w okolicznych zakładach przemysłowych, a po skończonej dniówce w zakładzie pracy szli jeszcze do pola. Kobiety zaś zajmowały się domem, dziećmi, ale też pracami przy gospodarstwie domowym.

W prace na gospodarstwie zaangażowani byli wszyscy domownicy, nie wyłączając dzieci. W tym względzie sytuacja również niewiele się zmieniła (znów przynajmniej do lat siedemdziesiątych XX wieku).

My jako dzieci pomagali w suszeniu siana, takie prace gospodarskie. Można powiedzieć, że mama kręciła calym tym interesem. Bo tata — kiedy? [...]. Jeszcze $w$ tamtych latach, jak gospodarka nie byta tak rozwinięta, to on przychodzac $z$ nocnej zmiany, od razu szedt ręcznie siec kosa. To jest nie do opowiedzenia. Ci ludzie żyli, żeby robić, czy robili, żeby żyć, nie wiem. Ciężko byto. [M_P3]

Oczywiście wspominam prace w polu. Bytam wtaczana we wszystkie prace - przy sianokosach, przy kopaniu ziemniaków, przy żniwach. Jako dzieci byliśmy $w$ to wtaczani i wcale żeśmy się nie buntowali, bo nam się to bardzo podobało. Szczególnie 
kopanie ziemniaków, potem palenie ognisk, badyli, pieczenie ziemniaków. To była dla nas bardzo duża atrakcja. [...] Ja już pasania krów nie pamiętam, natomiast sianokosy, suszenie siana pamiętam bardzo dobrze. [K_P3]

To już jak się miało te 10-12 lat to się chodziło paść krowy. To sięchodziło paść krowy, to my znowu pokombinowali, to się grało $w$ pitkę, tu tego, krowy gdzieś poszty i sie ich szukało całe drugie pół dnia, no ale tak to wygladało. Tak wygladało dzieciństwo tego rocznika 52, 53, 54, 55, 56 do rocznika 65 . [M_P3]

W świetle uzyskanych wypowiedzi można stwierdzić, że w wielu przypadkach kobiety zarządzały gospodarstwem domowym, włączając dzieci $\mathrm{w}$ wiele prac. Warto dodać, że najmłodsi badani, których dzieciństwo przypadało na lata osiemdziesiąte i dziewięćdziesiąte XX wieku, nie mówili już o konieczności pomocy w pracach gospodarskich, gdyż dezagraryzacja w Bojszowach w ostatnich dekadach XX wieku skutkowała także ograniczeniem obowiązków nakładanych na dzieci.

Wspomnienia ciężkiej pracy przeplatają się w wypowiedziach badanych $z$ wątkami przyjemniejszymi, jak choćby palnie ognisk na kartoflisku lub granie w piłkę na pastwiskach. Były to $z$ jednej strony swoiste nagrody za wykonanie ciężkiej pracy, a z drugiej strony czynnik wzmacniania więzi społecznych pomiędzy mieszkańcami. $Z$ wypowiedzi badanych wynika zresztą, że generalnie praca w polu, zwłaszcza w okresach jej największego nasilenia podczas żniw, sianokosów czy wykopków, była elementem integrującym działania całych rodzin.

Żniwa, sianokosy to szło się cata rodzina. Dziewczyny, jak byty młodsze, to ze szkoty się przychodzito i się szło pomagać rodzicom, czy przy zwierzętach, czy przy wypasaniu krów. Każdy w tym czasie miat można powiedzieć, jak tak analizowałem nie tak dawno, to praktycznie minimum co drugi dom, to była przynajmniej jedna krówka. Każdy coś tam gospodarzyt, miat jakieś poletko, każdy coś tam miat, czy jakiegoś świniaka, krowa to praktycznie była $w$ każdym... Jeden miat więcej drugi mniej, w zależności od posiadanego pola no i się chodziło można powiedzieć grupowo [paść - przyp. aut.]. Łąki byty na tym... akurat przy nas, bo jak babcia podzielita, to wujkowie, cała rodzina się spotykała na łące. Jeżeli byty sianokosy, a na polach czy przy żniwowaniu, czy przy kopaniu ziemniaków, bo to wszystko byto ręczne wtedy, to się rodziny spotykaty. Zawsze mama zostawała $w$ domu i przynosiła później, jak to się po ślasku nazywa swaczyna, czyli positek. Zawsze tam się robiło przerwę i się po prostu pracowato od rana do wieczora $w$ okresie wakacyjnym. A tak to po szkole się pomagato, tak siostry, jak $i$ ja. No i tak praktycznie wydaje mi sie, że tak byto $w$ większości rodzin. [M_P3]

Równie ważne jak sama praca było, jak pokazuje zacytowana wypowiedź, przyniesienie posiłku pracującym w polu. Najczęściej było to zadanie matki lub żony gospodarza. Generalnie w Bojszowach praca w polu 
jeszcze w latach sześćdziesiątych i siedemdziesiątych XX wieku przybierała formę przedsiębiorczego familizmu, czyli postawy „która zakładała konieczność uwzględniania $\mathrm{w}$ swoich planach także interesów rodziny i najbliższego otoczenia" (Bukraba-Rylska 2013, s. 100).

W opowieściach bojszowian bardzo często pojawiał się wątek wzajemnej pomocy w wykonywaniu prac rolniczych.

Co mi się zawsze podobało: jak teściu szedt z kosa kosić takę, to nikt nie wołat , chodźcie mi pomóc", a tu się schodzit jeden $z$ drugim i zajmowali się wspólnie praca. To byto miłe. Potem pili sobie kawę, napili się piwka. Teraz ludzie się odgradzaja, sadza te tuje, każdy szuka niezależności. [M_P3]

Jak to mówili zawsze: Maryjko, czy Helenko, przyjdź mi tam. No to prziszła i takie odróbki byty. To ty mi zorasz pole, a ja ci przyjdę odrobić. Takie byto kiedyś. Nie płacito się pieniędzmi. Przyjdź mi na odrobek, a jak człowiek przyszedt na odrobek, to trzeba byto robić. [M_P2]

Z uzyskanych w trakcie badań wypowiedzi wyłania się pozytywny obraz relacji sąsiedzkich lub sąsiedzko-rodzinnych związanych z prowadzeniem wspólnych prac na roli. Co ciekawe, badani często wspominają, że praca często łączyła się z późniejszym, również wspólnym, odpoczynkiem - przy ognisku i pieczeniu ziemniaków (co praktykowane było podczas wykopków) czy przy kawie lub piwie, spożywanych już raczej przy domu. $\mathrm{Z}$ wypowiedzi badanych wyraźnie przebija nostalgia i idealizacja czasów wspólnej pracy i odpoczynku po pracy. Jest to zresztą wątek typowy, zwykle dostrzegany w badaniach nad pamięcią zbiorową.

Z uzyskanych informacji wynika także, że wspólnota prac często opierała się na systemie wzajemnych powinności - odrobków. Zasady wzajemnej pomocy i świadczeń były niepisane i jasne dla mieszkańców Bojszów. Najczęściej chodziło o mniej więcej równoważny czas pracy na rzecz innego uczestnika procesu wzajemnej pomocy. Inaczej jednak odrabiało się prace świadczone ręcznie, a inaczej te związane $z$ wykorzystaniem urządzeń mechanicznych lub pożyczeniem konia, które wymagały większego wkładu „odrabianej” pracy. Według Lyski (2002, s. 95) w latach pięćdziesiątych XX wieku oprócz typowego przelicznika „na godziny pracy” obowiązywała też zasada odnosząca się do użyczenia konia z zaprzęgiem: „1 dniówka konnego zaprzęgu równała się 4 dniówkom odrobku ręcznego" ${ }^{5}$. Odrobkowi najczęściej nie towarzyszyły świadczenia pieniężne, które wchodziły w grę w niektórych sytuacjach związanych $z$ wykorzystywaniem maszyn i urządzeń rolniczych.

${ }^{5}$ Henryka Wesołowska (1991, s. 224 ) podaje: „1 dzień pracy koniem równał się 3 dniom pracy ręcznej kobiety, a 2 dniom mężczyzny", nie określa przy tym, jakich lat to dotyczyło. 
Myśmy mieli jedna z nielicznych w Bojszowach maszyn do młócenia. To jeszcze w latach siedemdziesiatych to trzy albo cztery takie maszyny $w$ Bojszowach byty, które całe Bojszowy omtócity. No to przy tej maszynie trzeba byto stać. Przyjechało dwóch, trzech przyjechato, a do obstugi maszyny potrzeba byto 4-5. To ja tam z boku stawatem i pilnowałem czy wiazałem, bo tam już nie wiązała ta maszyna i trzeba byto stać i pilnować. [...]

B: A to płacono za to, czy jakoś na innych zasadach funkcjonowało?

R: To znaczy to byt jakiś sposób na zarobek. Oczywiście ci co przyjeżdżali to płacili, bo prąd się zużywat no i myśmy też jakiś czas, mama, traciła, ale ja na to bytem zły, no bo jak ja widziałem, że to nie byto tyle, że można sobie było kokosy zbić.

B: Zwrot kosztów?

R: Tak. Coś tam jeszcze ponad to. Już nie pamiętam tych stawek.

B: To nie o to chodzi. Bardziej o sama zasadę działania.

R: Ale to było śmiesznie niskie pieniaddze. Ja byłem zły na to, że musiałem tam stać. Praktycznie nic z tego nie miałem. Mama coś tam miała, a trudno byto im odmówić, $\dot{z}$ eby ten... No $i$ w zasadzie to co roku ci sami przychodzili, z tej naszej ulicy to praktycznie wszyscy ci co mieli pola to u nas młócili. [M_P3]

Oprócz prac polowych wzajemne świadczenia i pomoc dotyczyły też innych prac.

Wie pan co, tak jak kiedyś byto to było catkiem inaczej. Było tak rodzinnie. Sąsiad sasiadowi szedt pomóc, czy do rodziny. Nikt nie brat pieniędzy. Ten wujek się budowat, to cegła my robili w cegielnioku. Tata umiot robić te cegły $i$ stawiat piec, co sie wypalało. A my wszyscy latali $i$ deptali, bo to trzeba byto urobić. I potem my te cegty też nosili, bo one wyschty i my nosili do pieca, żeby je ułożyć. Nikt nie brat pieniędzy. To była taka pomoc jeden drugiemu. Ten potrzebowot szedt, zaś ten potrzebowot szedt $i$ nikt się nie pytat o zapłata. Dzisiaj jeden drugiemu za darmo nie zrobi nic, bo się pytająile. [K_P2]

Praca w gospodarstwie angażowała większość mieszkańców Bojszów. Niezależnie od wielkości gospodarstwa wspólnota gospodarowania była niewątpliwie elementem więziotwórczym społeczności. W pracach rolniczych wyraźnie uwidaczniała się wspólnota losu i zależności zarówno od innych mieszkańców (zwykle krewnych lub sąsiadów), których pomoc często była niezbędna do wykonania określonych prac, jak od przyrody i warunków pogodowych. Prace polowe wyznaczały jeden z rytmów życia bojszowskiej społeczności do lat siedemdziesiątych lub osiemdziesiątych XX wieku (w zależności od tego, jak długo prowadziło się gospodarstwo). Z czasem — o czym pamiętają rozmówcy z wszystkich pokoleń — zaczęto odchodzić od uprawy i hodowli.

To się rozleciało wszystko. W latach siedemdziesiatych. Ludzie poszli do przemystu i nie patrzeli już na gospodarko, na to. Pola stały ugorem. [M_P2] 
Ale $w$ miarę zmieniania się $w$ ogóle charakteru naszej gminy tutaj, bo to potem już mniej się hodowało, mniej się tutaj... I tego ubywało. W zasadzie pole się tam uprawiato to co dla siebie. W tych latach osiemdziesiatych to sie pozmieniało. [M_P3]

Około 30 lat temu się dopiero przestało [gospodarzyć - przyp. aut.]. Potem jak "Czeczott" zaczęli budować, to potem robili te waty i oni nam te łąki już potem zdewastowali praktycznie $z$ tamtej strony i potem nam dawali odszkodowanie, a potem $w$ końcu to wykupili. Zapłacili, nie tyle ile było warte, ale coś tam zapłacili. Poszło to na konto kopalni „Czeczott”. [M_P1]

Ci co w przemyśle pracowali, nie, to mieli dużo lepiej, jak tu, ci co na roli, na polach. [M_P2]

Bliskość zakładów przemysłowych i stosunkowo duża łatwość znalezienia $\mathrm{w}$ nich pracy powodowała stopniową rezygnację $\mathrm{z}$ zajęć rolniczych, które z czasem zwykle ograniczyły się do przydomowych ogródków. Z pracy w przemyśle, a zwłaszcza w kopalniach, można było uzyskać większy dochód.

Inną przyczyną szukania pracy w przemyśle była świadomość tego, jak ciężka jest praca rolnicza. Nawet bycie górnikiem w zestawieniu z nią nie przerażało. Jeden $z$ badanych - emerytowany górnik - poznawszy pracę na gospodarstwie w okresie dzieciństwa i młodości, nie wiązał swojej przyszłości z rolnictwem, a jednym $z$ kryteriów wyboru małżonki było nieposiadanie przez nią gospodarstwa:

...ale generalnie jako dziecko i to mi zostało... Że jak później na zolety to patrzatem, czy jej jakiś ogon nie wystaje z jakiegoś... Powiedziałem sobie żadnego gospodarstwa, żadnej. Zero, po prostu zero, tak bytem zrażony do tego. [M_P3]

Niebagatelne znaczenie dla podejmowania pracy w kopalniach (najczęściej była to kopalnia „Ziemowit” w Lędzinach) miała oczywiście miejscowa tradycja związana $z$ „chodzeniem do pracy ku hutom”. W latach powojennych było to o tyle łatwiejsze, że „huty” pojawiły się znacznie bliżej niż te, do których mieszkańcy Bojszów dojeżdżali w latach międzywojennych.

To byty lata siedemdziesiąte i jeszcze wcześniej, gdzie powstawała kopalnia... znaczy powstawata. Robit brat, robił ojciec, robit dziadek. U nos dziadek robit, ojciec robil, ja poszedtem do górnictwa, brat poszedt do górnictwa i tak samo wujkowie: jeden, drugi, trzeci wszyscy robili na kopalniach. Dlaczego? No przede wszystkim to sie wynosito $z$ domu, to się wynosito $z$ tej kultury, to się wynosito $z$ tego, że to byto obowiazek. Wiadomo, że trzeba byto rano wstać, bo ten autobus odjeżdżat. Nie byto samochodów, nie byto nic i to byta taka... To się wynosito $z$ domu. Czas. Nie wyobrażam sobie, żebym $w$ domu, tam autobus jechat 5.20, żeby dziesięć po piatej nie wyjść $z$ domu na autobus. I to byt taki rygor. Przychodzito się z roboty to byt obiad, bo juz mama wszystkim naszykowała ten obiad. Dyscyplinowato nas do tego poszanowa- 
nie czasu, poszanowanie tego, że mama ten obiad zrobiła, poszanowanie tego, że jest robota i jest zarobek. [...]

B: Pan już dojeżdżat na kopalnię autobusem. A ojciec jak dojeżdżał? Też autobusem? R: Autobusem. Byty bilety miesięczne, które się na kopalni w okienku... Miałeś bilet, co miesiąc się szło po ten bilet, planistka wydawała bilety. To byto normalne. Tok życia. [...]

B: A z Bojszów w tym Pana pokoleniu dużo osób na kopalni pracowało?

R: W tamtych latach powiem panu szczerze. Przystanek, który tu byt na, jest, na 931 koło baru, koło „Łowieckiej” to rano jechało pięć autobusów na kopalnię. To jechaty autobusy na pierwsza zmianę. [...] Lata 70-te, 80-te, 85-te do 90 roku to w Bojszowach mieszkańcy Bojszów pracowali albo na kopalni „Piast”, na „Ziemowicie”, na nowym „Piaście” i ERG. To byty trzy takie zakłady, czy cztery, gdzie większość ludzi była zatrudniona. Po kolei, jakbyśmy szli Jedlińska, czy w inna to $z$ każdego domu byt górnik. Większość rodzin było związane z górnictwem. [M_P3]

Przytoczona dłuższa wypowiedź badanego oprócz wątku związanego $z$ podziałem ról $\mathrm{w}$ rodzinie podnosi inne kwestie ważne dla bojszowian. Pojawiały się one także w innych wywiadach. Po pierwsze, praca na kopalni, szczególnie w latach siedemdziesiątych i osiemdziesiątych XX wieku, w Bojszowach była powszechna. Wynikało to z tradycji i kultury zakorzenionej zarówno w poszczególnych rodzinach, jak i w całej społeczności. Wydaje się, że praca na kopalni, w której pracowali krewni i znajomi, był to pierwszy, a dla niektórych mężczyzn jedyny, pomysł na drogę zawodową. Raczej odstępstwo od takiej ścieżki zawodowej mogło budzić zdziwienie niż pójście do pracy na kopalnię. Po drugie, wypowiedź badanego pokazuje, że kopalnia organizowała wiele nawet drobnych spraw bytowych, istotnych dla codziennego funkcjonowania. Po trzecie, rozmówca wyraźnie wskazuje na szczególny rytm życia miejscowości, gdyż znaczna część mieszkańców pracowała w jednym zakładzie pracy. Wyjście z domu tuż po piątej rano, dojście na przystanek i wspólny dojazd do pracy stawały się rutynowe, a także wyznaczały rytm życia miejscowości. Rytm ten był już niezależny od czasu przyrodniczego i prac polowych, choć w miesiącach letnich udający się do pracy mogli spotykać tych, którzy jeszcze prowadzili gospodarstwa i jechali w pole. W połowie lat siedemdziesiątych XX w Bojszowach „ponad $80 \%$ ludności żyło z pracy w przemyśle, choć $\mathrm{w}$ gminie istniało 1156 gospodarstw chłopsko-robotniczych powyżej 0,5 ha, na które nałożone były obowiązkowe dostawy zboża, mięsa i mleka" (Lysko 2002, s. 133-134). Bliskość okręgu przemysłowego powodowała, że proces dezagraryzacji w Bojszowach był nieco szybszy niż średnio w województwie katowickim, gdyż - jak podaje Wanda Mrozek (1972, s. 132) - w roku 1970 22,3\% mieszkańców wsi ówczesnego województwa katowickiego utrzymywało się z rolnictwa. 
Tym, czym kopalnie były dla bojszowskich mężczyzn, tym dla części bojszowskich kobiet był bieruński ERG (przed wojną Lignoza), podobnie jak w latach międzywojennych.

Bo przecież kobiety, które tu byty, to $w$ większości nie pracowaty, ale byt ten okres, że część tych kobiet pracowało. Głównym pracodawca tych kobiet to byt ERG. Zakłady chemiczne ERG i one większość piechota tam chodzity. [M_P3]

Praca dla bojszowskich kobiet często trwała jedynie do momentu urodzenia dziecka, a z czasem kolejnych dzieci. Kobiety rezygnowały wówczas z pracy, by zajmować się domem i gospodarką:

Poszłach tu do fabryki do roboty i zaś we fabryce robiłach. Trzy lata. A potem sie mi dziecko już urodziło to już musiałak być przy dziecku $i$ w doma gospodarzyła. Już nigdziek nie szła. [K.P1]

Bywało też, że kobiety wracały do pracy po urlopie macierzyńskim:

W Pszczynie pracowałam pót roku, potem poszłam na rok macierzyńskiego, nie macierzyński tylko macierzyński bezpłatny [urlop wychowawczy — przyp. aut.], a potem dostałam znowu propozycję z ERG-u. Zadzwonili do mnie, żebym wrócita na ERG. Także tam się dobrze pracowato na ERG-u. No dobrze się pracowato. Ja pracowatam $w$ kosztach, potem miałam stanowisko kierownicze, ale to już po iluś tam latach. [K_P2]

Zdarzało się, że praca w ERG-u była dla bojszowianki koniecznością po śmierci męża: Po wojnie ojciec nie przyszedt, to mama pracowała $w$ ERG-u [M_P2].

Niewątpliwym atutem pracy w bieruńskim ERG-u był fakt, że ze względu na profil zakładu dniówki w wielu wydziałach były krótsze, sześciogodzinne, można było liczyć także na wcześniejsze emerytury. Jednak praca z materiałami wybuchowymi była niebezpieczna, zdarzały się wypadki. One również w Bojszowach są pamiętane.

$\mathrm{R}$ : Ja też przepracowata [w ERG-u] 35 lot. I to też byto w niebezpiecznych warunkach, że 6 godzin.

B: Tam też byty te tragiczne historie, wybuchy.

R: No byty. Jeden se pamiętom, bo ten drugi to taka koleżanka zginęła $w$ magazynie, ale ten jeden... Jo robiła na swoim stanowisku i pamiętam, że wybucht dynamit, to te moje krzesło do góry i nazot. Taki byt ten wybuch, że nas uniosto, i taki huk niesamowity. Wtedy trzech ludzi zginęło. No i Manek co miot ten wybuch co zostot niewidomy. To też byto, ale ta koleżanka to tak ją rozszarpato, że ino fleki po budynku i naprzeciw budynku. Tyla byto. [K_P2]

Oczywiście w ERG-u pracowali także bojszowscy mężczyźni, choć nie było to dla nich tak powszechne miejsce pracy jak dla kobiet. Jeden $z$ badanych wspominał, że przepracował tam 35 lat. Bieruński ERG stanowił 
zatem alternatywę dla tradycyjnych ról związanych $\mathrm{z}$ pracą $\mathrm{w}$ domu i na gospodarce. Praca zawodowa nie zwalniała jednak bojszowskich kobiet $z$ realizowania tradycyjnych ról domowych, a gdy pogodzić się ich nie dało, rezygnowały $z$ pracy zawodowej na rzecz prowadzenia domu i zajmowania się gospodarstwem.

Drugim rodzajem działalności zarobkowej kobiet był handel w okolicznych miastach. $Z$ relacji badanych wynika, że sprzedaż produktów wytworzonych w gospodarstwach: masła, śmietany, serów, ale też runa leśnego, rozpoczęta przed drugą wojną światową, była kontynuowana w latach Polski Ludowej.

R: Byty też takie kobiety, które jaja wozity, masto. Tam [w miastach] wszystko kupowali. [...] To byto parę takich kobiet co one stale jeździty tam. Miaty swoich odbiorców i stale wozity: masto, jajka, wszystko co byto, jagody, grzyby.

B: To jeszcze za starej Polski, czy już po wojnie?

R: Wtedy i po wojnie też jeszcze, za komunistów też jeszcze. [M_P1]

A babcia nie pracowata. [...] Zajmowata się handlem, jeździła jak to się godo ku hutom, $z$ serem, $z$ mastem, $z$ jajkami. [K_P3]

Do lasu tośmy chodzili, nawet przedtem zbierali u nas jagody i sprzedawali. I to byty takie kobiety, panie miejscowe, co te jagody od nas skupowaty i one jeździty z tym, z tymi jagodami, z tym wszystkim jeździty do Mystowic albo do Katowic, do cukierni. I tam to zawozity albo do Pszczyny. W koszykach, autobusem, bo kiedyś tatwo byto przejechać. WPK [Wojewódzkie Przedsiębiorstwo Komunikacyjne] jeździto świetnie. Po pracy można byto wsiaść do autobusu i jeszcze zrobić zakupy w Katowicach $i$ wrócić. [K_P2]

Niektóre bojszowianki wiązały się zatem w stałą sieć dystrybucji towarów wytwarzanych w gospodarstwach. Taki handel uzupełniał niedobory panujące na oficjalnym rynku, a bojszowskim rodzinom przynosił dodatkowy dochód. W wypowiedziach badanych warto zwrócić uwagę na wątek związany $z$ dojazdem do Katowic, Mysłowic czy Pszczyny. Zawiera on pozytywne oceny ówczesnego systemu komunikacji publicznej, który jest wspominany jako funkcjonalny i dający możliwość bezpośredniego, choć długiego, dojazdu do bliskich miast.

Trzy szerzej omówione formy zarobkowania: praca na kopalni, praca w ERG-u oraz handel produktami spożywczymi, to nie wszystkie sposoby pracy zarobkowej poza gospodarstwem. Bojszowianie wspominali o pracy w kuźni, w piekarni, w Urzędzie Gminy, zwożeniu mleka, prowadzeniu własnej małej firmy czy pracy listonosza. Praca rolnicza dla wielu bojszowskich rodzin już od lat była jedynie uzupełnieniem aktywności zawodowej poza miejscem zamieszkania. Dwuzawodowość była typowa, zwłaszcza w latach Polski Ludowej. Częściej dotyczyło to mężczyzn niż 
kobiet i zwykle polegało na łączeniu pracy na kopalni z pracą w gospodarstwie. W latach powojennych, zwłaszcza po otwarciu kopalni „Ziemowit” w Lędzinach, sytuacja zmieniła się w porównaniu do lat przedwojennych o tyle, że mężczyźni nie jeździli już ku hutom na tydzień, by wracać jedynie na niedzielę — dzięki rozwijającemu się z czasem systemowi komunikacji zbiorowej dojazd i powrót $\mathrm{w}$ tym samym dniu umożliwiały większe zaangażowanie po pracy zawodowej w obowiązki gospodarcze. Część kobiet funkcjonowała w podobnym systemie, a najbardziej popularnym miejscem pracy był bieruński ERG. Innym ważnym zajęciem zarobkowym kobiet był handel produktami spożywczymi w pobliskich miastach. Rozwijane indywidualne sieci sprzedaży pozwalały na znaczące uzupełnienie domowych budżetów bojszowskich rodzin. To zresztą ciekawy wątek pokazujący zaradność kobiet i wychodzenie $z$ ról ograniczonych do życia domowego i gospodarskiego, a zarazem swoista forma dwuzawodowości.

Lata osiemdziesiąte XX wieku to w Bojszowach okres kontynuacji procesu dezagraryzacji: „W 1991 roku ponad 1500 osób z gminy Bojszowy pracowało w trzech nieodległych kopalniach (735 na «Ziemowicie», 561 na «Piaście» i 306 na «Czeczocie»), 142 w bieruńskiej fabryce ERG i 118 w Fabryce Samochodów Małolitrażowych" (Lysko 2002, s. 172). Pod względem struktury zatrudnienia Bojszowy były już wówczas właściwie miejscowością przemysłową. Dziesięć lat później, według danych z Narodowego Spisu Powszechnego z 2002 roku, z rolnictwa utrzymywało się tam 1,8\% mieszkańców (Zagała 2006, s. 27). W województwie śląskim odsetek ten był podobny - dla 3,4\% osób rolnictwo było głównym lub dodatkowym źródłem dochodów (Duś 2014).

Współcześnie w Bojszowach pozostało jeszcze kilka większych gospodarstw rolnych, ale wieś stała się miejscowością, której mieszkańcy pracują $\mathrm{w}$ drugim sektorze gospodarki (głównie w kopalniach, choć już nie tak licznie jak w latach siedemdziesiątych XX wieku) lub trzecim.

\section{PODSUMOWANIE — PRACA W PAMIĘCI ZBIOROWEJ MIESZKAŃCÓW METROPOLITALNEGO SUBURBIUM}

Badania nad pamięcią zbiorową potwierdziły znaczenie pracy dla społeczności wiejskiej. W analizowanym przypadku wsi Bojszowy, położonej w pobliżu Górnośląskiego Okręgu Przemysłowego, rozmowy o pracy nie koncentrowały się jednak na rolnictwie, ale w znacznej części dotyczyły pracy zarobkowej w przemyśle. To swoisty wyróżnik wsi górnośląskich, potwierdzający zarazem, że „istnieje wiele ścieżek przemian wsi i rolnictwa" (Gorlach 2004). Paradoksalnie pamięć o pracy w rolnictwie częściej 
odnosiła się do lat powojennych, w których powszechna już była praca w sektorze przemysłowym, a wspominając lata wcześniejsze, przedwojenne, badani częściej i szerzej mówili o podejmowanej przez ich przodków pracy $\mathrm{w}$ przemyśle. Wyjaśnienia tego fenomenu, poza zmianą pokoleniową, można poszukiwać w mechanizmach pamięci autobiograficznej, $\mathrm{w}$ tym, że lepiej zapamiętuje się wydarzenia i procesy mniej związane z codziennością (zwłaszcza teraźniejszą).

Bojszowska pamięć o pracy ma wyraźnie etosowy charakter. Łączy się $z$ takimi wartościami jak: pracowitość, solidność, sumienność, uczciwość, dyscyplina, posłuszeństwo, szacunek dla przełożonych, dobra organizacja (Swadźba 2001, s. 47). Były one ważne niezależnie od tego, czy chodziło o pracę w przemyśle, czy o pracę rolniczą. Dla bojszowian, podobnie jak dla pochodzącego ze Śląska Cieszyńskiego Jana Szczepańskiego (2003, s. 34), robota była „najistotniejszą treścią życia [...], miarą wartości człowieka, codziennym sprawdzianem jego możliwości”. Co więcej, „próżnowanie i lenistwo uważano nie tylko za wadę charakteru, ale i ciężki grzech” (Wesołowska 1991, s. 221). Osoby, które nie miały zajęcia, jak choćby przed wojną elwry, nie cieszyły się szacunkiem wiejskiej społeczności. Wyraźnie więc widać, że pamięć o dobrej, rzetelnej pracy jest elementem tożsamości bojszowskiej społeczności. Dziś zewnętrznym tego przejawem jest dbałość o przydomowe ogródki i obejście, co zresztą wynika też z dawniejszych praktyk uwarunkowanych normatywnie, nakazem sprzątania w sobotnie popołudnia nie tylko okolic swojego domostwa, ale także wiejskich dróg.

Wątek pracy ma w pamięci zbiorowej bojszowskiej społeczności wyraźnie pozytywne konotacje. Pamięć o ciężkiej pracy rodziców i dziadków, ich zaradności, współpracy w ramach rodziny lub grup sąsiedzkich buduje pozytywny obraz grupy własnej. Taki obraz kontrastuje $z$ wypowiedziami dotyczącymi współczesności, w której badani dostrzegają procesy indywidualizacji i dezintegracji zachodzące także w ich własnej społeczności.

Zasoby pamięci zbiorowej bojszowian dobrze ilustrują też przeobrażenia wsi związane $z$ procesami proletaryzacji, dezagraryzacji i gentryfikacji społecznej (Halamska 2016). Dwa z tych trzech procesów zostały wyraźnie przedstawione $\mathrm{w}$ przywoływanych wypowiedziach badanych. Trzeba jednak podkreślić, że proces proletaryzacji w Bojszowach, ale też $\mathrm{w}$ wielu miejscowościach Górnego Śląska, rozpoczął się znacznie wcześniej niż w innych regionach Polski. Renta położeniowa dawała mieszkańcom Bojszów możliwość udawania się do pracy ku hutom już w latach międzywojennych. Co ważne, jak pokazały badania, ten sposób zawodowego funkcjonowania zachował się w pamięci zbiorowej bojszowian. Wskazuje to na jego istotną rolę w świadomości mieszkańców. W odniesieniu do przeło- 
mu XIX i XX wieku pisała o tym Irena Bukowska-Floreńska (2007, s. 129): „Praca $\mathrm{w}$ górnictwie stała się wartością — była równie pożądana jak ziemia, a nawet bardziej, bo dawała w perspektywie mimo wszystko pewną niezależność".

Możliwość pracy w przemyśle spowodowała też nieco szybszy proces dezagraryzacji, choć $\mathrm{w}$ świetle wypowiedzi badanych na dobre rozpoczął się on w latach siedemdziesiątych XX wieku. Trzeba tu jednak uwzględniać, że gospodarstwa bojszowian najczęściej nie były duże, dlatego nawet pracując $\mathrm{w}$ przemyśle można je było utrzymywać, oczywiście przy znacznym wysiłku całej rodziny.

Proces gentryfikacji społecznej nie był zasadniczo przedmiotem tej analizy, ale nawet dane dotyczące liczby mieszkańców gminy Bojszowy wyraźnie wskazują, że w XXI wieku Bojszowy stają się atrakcyjnym miejscem zamieszkania dla osób pracujących w Górnośląsko-Zagłębiowskiej Metropolii. Podobnie jak w innych miejscach w Polsce, ale też w innych społeczeństwach Globalnej Północy (zob. Gorlach, Starosta 2018, s. 37-38), napływ nowych osób spoza wiejskiego świata i wzmocnienie funkcji rezydencjalnej (Podedworna 2006, s. 227) wywołuje — dostrzegany w wywiadach przez badanych - problem integracji społecznej między „nowymi” i „starymi” mieszkańcami. Bojszowy stały się zatem wsią podmiejską (Halamska 2016, s. 75-76), a może nawet metropolitalnym suburbium, w którym wspólnota lokalnej pamięci podlega erozji w związku z napływem nowych mieszkańców. Rolnicza przeszłość miejscowości jest nieznana przybyszom, czasem trudna do zrozumienia, a zasłyszane opowieści związane z wyjazdami ku hutom pozostają przynależne do odległej historii i niekonieczne będą przekazywane kolejnym pokoleniom.

\section{BIBLIOGRAFIA}

Assmann Jan, 1995, Collective Memory and Cultural Identity, „New German Critique”, nr 65, s. $125-133$.

Assmannn Jan, 2009, Kultura pamięci, tłum. Anna Kryczyńska-Pham, w: Magdalena Saryusz-Wolska (red.), Pamięć zbiorowa i kulturowa. Wspótczesna perspektywa niemiecka, Universitas, Kraków, s. 59-99.

Babbie Eearl, 2003, Badania społeczne w praktyce, tłum. Witold Betkiewicz i in., Wydawnictwo Naukowe PWN, Warszawa.

Bierwiaczonek Krzysztof, Nawrocki Tomasz, 2020, Pomiędzy trauma wojny a codziennościa. Pamięć zbiorowa mieszkańców górnoślaskiej wsi Bojszowy, Scholar, Warszawa.

Bierwiaczonek Krzysztof, Tyrybon Małgorzata, Nawrocki Tomasz, 2001, Lędziny 2000 — portret miasta, Mega-Press II, Lędziny.

Bukowska-Floreńska Irena, 2007, Rodzina na Górnym Ślasku, Wydawnictwo Uniwersytetu Śląskiego, Katowice. 
Bukraba-Rylska Izabela, 2013, Socjologia wsi polskiej, Wydawnictwo Naukowe PWN, Warszawa.

Coman Alin, Brown Adam D., Koppel Jonathan, 2009, Collective Memory from a Psychological Perspective, „International Journal of Politics, Culture, and Society”, t. 22 (2), s. 125-141 .

Duś Edward, 2014, Rolnictwo województwa ślaskiego, w: Encyklopedia Województwa Ślaskiego. Tom I (2014) (http://ibrbs.pl/mediawiki/index.php/Rolnictwo_województwa_śląskiego [dostęp: 22.07.2019]).

Eyerman Ron, Madigan Todd, Ring Magnus, 2017, Cultural Trauma, Collective Memory and the Vietnam War, „Croatian Political Science Review”, t. 54 (1-2), s. 11-31.

Gerlich Marian Grzegorz, 2016, Pamięć zbiorowa a transformacja symboliczna. Przypadek górnośląski, w: Marian Grzegorz Gerlich, Śląski witraż. Prawdy. Złudzenia. Mity, Wydawnictwo Śląsk, Katowice, s. 177-203.

Giddens Anthony, 2006, Nowoczesność i tożsamość, tłum. Alina Szulżycka, Wydawnictwo Naukowe PWN, Warszawa.

Gorlach Krzysztof, 2004, Socjologia obszarów wiejskich. Problemy i perspektywy, Scholar, Warszawa.

Gorlach Krzysztof, Starosta Paweł, 2018, Rodzinne gospodarstwa rolne w spotecznościach wiejskich. Zmiany organizacji życia społecznego wsi w świecie nowoczesnym i ponowoczesnym, „Roczniki Nauk Społecznych", t. 46, nr 4, s. 17-42.

Halamska Maria, 2016, Struktura społeczno-zawodowa ludności wiejskiej w Polsce i jej przestrzenne zróżnicowanie, „Wieś i Rolnictwo”, nr 1, s. 59-85.

Halamska Maria, 2018, Meandry pamięci i niepamięć, w: Sylwia Michalska, Maria Halamska, Marek Kłodziński (oprac.), Sto lat mojego gospodarstwa. Pamiętniki mieszkańców wsi, Polskie Wydawnictwo Rolnicze-Instytut Rozwoju Wsi i Rolnictwa PAN, Poznań-Warszawa, s. $49-66$.

Halbwachs Maurice, 2008, Społeczne ramy pamięci, tłum. Marcin Król, Wydawnictwo Naukowe PWN, Warszawa.

Hewer Christofer J., Roberts Ron, 2012, History, Culture and Cognition: Towards a Dynamic Model of Social Memory, „Culture and Psychology”, t. 18(2), s. 167-183.

Kaczmarek Ryszard, 2018, Bojszowy na skrzyżowaniu wielkiej i małej historii, w: Maria Lipok-Bierwiaczonek (red.), Bojszowy. W kręgu badań nad przeszłościa i dziedzictwem kulturowym, Gmina Bojszowy, Bojszowy, s. 15-32.

Kaźmierska Kaja, 2012, Wspótczesna pamięć komunikacyjna i kulturowa. Refleksja inspirowana koncepcją Jana Assmanna, w: Elżbieta Hałas (red.), Kultura jako pamięć. Posttradycjonalne znaczenie przeszłości, Nomos, Kraków, s. 43-62.

Kijonka Justyna, 2016, Tożsamość wspótczesnych Ślazaków. Studium socjologiczne, Wydawnictwo Śląsk, Katowice.

Kończal Kornelia, Wawrzyniak Joanna, 2018, Provincializing Memory Studies: Polish Approaches in the Past and Present, „Memory Studies”, t. 11(4), s. 391-404.

Lipok-Bierwiaczonek Maria, 2018, Słowo wstępu. Bojszowy pod lupa badaczy, w: Maria Lipok-Bierwiaczonek (red.), Bojszowy. W kręgu badań nad przeszłością i dziedzictwem kulturowym, Gmina Bojszowy, Bojszowy, s. 7-14.

Lowenthal David, 1991, Przeszłość to obcy kraj, tłum. Irena Grudzińska-Gross, Maciej Tański, „Res Publica”, nr 3, s. 7-21. 
Lysko Alojzy, 2002, Bojszowy w XX wieku, Gminne Przedsiębiorstwo Komunalne, Bojszowy.

Mayntz Renate, Holm Kurt, Hübner Peter, 1985, Wprowadzenie do metod socjologii empirycznej, tłum. Wanda Lipnik, Państwowe Wydawnictwo Naukowe, Warszawa.

Martini Natalia, 2017, Praktykowanie czasu wolnego w sytuacji niedoboru i nadmiaru, „Przegląd Socjologii Jakościowej", t. 13, nr 4, s. 94-112.

Mrozek Wanda, 1972, Problemy socjologiczne województwa katowickiego, Śląski Instytut Naukowy, Katowice.

Nawrocki Tomasz, 2006, Trwanie i zmiana lokalnej społeczności górniczej na Górnym Ślasku. Na przykładzie Murcek, Wydawnictwo Uniwersytetu Śląskiego, Katowice.

Nijakowski Lech M., 2008, Polska polityka pamięci. Esej socjologiczny, Wydawnictwa Akademickie i Profesjonalne, Warszawa.

Nowak Jacek, 2011, Społeczne reguły pamiętania. Antropologia pamięci zbiorowej, Nomos, Kraków.

Podedworna Hanna, 2006, Przemiany zbiorowości wiejskich, w: Jacek Wasilewski (red.), Wspótczesne społeczeństwo polskie. Dynamika zmian, Scholar, Warszawa, s. 199-230.

Rajewski Adam, 2013, Rozważania na temat Assmannowskiej teorii pamięci, „Rocznik Antropologii Historii", t. 3, nr 1(4), s. 187-202.

Robotycki Czesław, 1997, Historia, tradycja, antropologia (tezy), „Polska Sztuka Ludowa. Konteksty", nr 1-2, s. 44.

Rosner Andrzej, Stanny Monika, 2018, Rozważania o pojęciu i procesie dezagraryzacji polskiej wsi, „Wieś i Rolnictwo”, nr 2, s. 281-292.

Runge Anna, 2017, Zróżnicowanie demograficzne obszarów wiejskich województwa śląsiego, w: Krzysztof Gasidło, Agata Twardoch (red.), Na wsi, czyli gdzie? Architektura, środowisko, spoteczeństwo, ekonomia wspótczesnej wsi, Wydawnictwo Politechniki Śląskiej, Gliwice, s. 42 -60 .

Saryusz-Wolska Magdalena, 2011, Spotkania czasu z miejscem. Studia o pamięci i miastach, Wydawnictwa Uniwersytetu Warszawskiego, Warszawa.

Strategia..., 2016, Strategia Rozwoju Gminy Bojszowy na lata 2016-2026, Bojszowy.

Swadźba Urszula, 2001, Śląski etos pracy. Studium socjologiczne, Wydawnictwo Uniwersytetu Śląskiego, Katowice.

Swadźba Urszula, 2012, Wartości - pracy, rodziny i religii - ciagłość i zmiana. Socjologiczne studium społeczności ślaskich, Wydawnictwo Uniwersytetu Śląskiego, Katowice.

Szacka Barbara, 2006, Czas przeszty, pamięć, mit, Scholar, Warszawa.

Szczepański Jan, 2003, Korzeniami wrosłem w ziemię, Muzeum Hutnictwa i Kuźnictwa, Urząd Miasta w Ustroniu, Ustroń.

Szmeja Maria, 2017, Ślask bez zmian. Ludzie, kultura i społeczność Ślaska w perspektywie postkolonialnej, Nomos, Kraków.

Szpak Ewelina, 2013, Mentalność ludności wiejskiej w PRL. Studium zmian, Scholar, Warszawa.

Welzer Harald, 2010, Re-Narrations: How Pasts Change in Conversational Remembering, „Memory Studies", t. 3(1), s. 5-17.

Wesołowska Henryka, 1991, Więzi rodzinne i sasiedzkie, w: Dorota Simonides (red.), Kultura ludowa śląskiej ludności rodzimej, Volumen, Wrocław-Warszawa, s. 213-227.

Zagała Zbigniew, 2006, Samodzielni, samorzadni, gospodarni. Bojszowy i Wyry - ocena pierwszej dekady, Śląskie Wydawnictwa Naukowe WSZNS, Tychy. 
THE CONCEPT OF WORK IN THE SOCIAL MEMORY OF THE INHABITANTS OF AN UPPER SILESIAN VILLAGE IN THE CONTEXT OF TRANSFORMATION PROCESSES IN RURAL AREAS

Tomasz Nawrocki, Krzysztof Bierwiaczonek (University of Silesia in Katowice)

\section{Abstract}

The subject of the article is collective memory of the concept of work among the inhabitants of the Upper Silesian village of Bojszowy. The author of the study employs the classic understanding of collective memory, while simultaneously pointing to the importance of the communication process and the diversity of information sources shaping it. Empirical data was collected during research conducted in 2018 using in-depth interview techniques. The research sample consisted of 30 rural residents. Analysis of the functioning of collective memory about work revealed the development processes-especially industrialization and deagrarianization-taking place in Bojszów. The analysis clearly shows the specificity of the Upper Silesian village, where these processes began relatively early, and work was associated not only with agriculture, but also with industry and trade.

Key words: collective memory, work, village, Upper Silesia, industrialization, deagrarianization

Słowa kluczowe: pamięć zbiorowa, praca, wieś, Górny Śląsk, industrializacja, dezagraryzacja 